From the Department of Child Health, Medical School, University of Pajajaran, Bandung

\title{
A Case of Perforation of the Gallbladder in Association with Typhoid Fever (Case Report)
}

\author{
by \\ PONPON IDJRADINATA, E. SUROTO-HAMZAH and \\ SUGIRI
}

\section{Introduction}

Typhoid fever is still common in Indonesia. Relapses occur in about 10 per cent of the cases, usually less severe than the primary attack, but sometimes exceeding the primary attack in severity and duration. In children complications are less frequent than in adults. The most serious is perforation of the intestine, which usually occurs at the end of the second week or at ithe beginning of the third week of the disease.

Hepatitis with icterus occurs occasionally and acute cholecystitis is a rare complication (Bradford, 1969).

Acute cholecystitis and cholangitis can occur toward the end of the second week, but may also develop in any stage of the disease. Perforation of the gallbladder may also occur in the course of typhoid fever (Sellek et al., 1951) with symptoms resembling those of intestinal perforation.

The preoperative diagnosis is almost always intestinal perforation (Kaye, 1969).

A study by Alisjahbana (1970) on 108 Salmonellosis cases in Bandung showed no complications at all. Isaac (1968) reported an incidence of intestinal perforation of 1 per cent, whereas Lozoya from Mexico City 6.35 per cent. Lozoya (1968) reported 4 patients with rupture of gallbladder out of 457 in children, and only one survived the operation; Sellek et al. (1951) however, reported more than 50 cases of this rupture.

In addition to involvement of the Peyer's patches, there are also extensive changes in the liver, and in the-

Received 8th. Jan. 1974. 
se cases parenchymatous degeneration next to jaundice is frequently found. Also small foci of lymphoid inflammation or minute areas of necrosis have been recorded, whereas abscesses are rare. Acute cholecystitis in association with typhoid fever varies in degree from mild catarrhal type to an extremely dangerous, phlegmonous or gangrenous form; the serious consequences of this complication are perforation and peritonitis.

The purpose of this paper is to report a case of rupture of gallbladder in a child in association with typhoid fever.

\section{Case Report}

H., a 5-year-old Indonesian boy was admitted to the Child Health Department Dr. Hasan Sadikin General Hospital, Bandung, on September 28,1971 , because of fever of 7 days and loss of appetite since 5 days. $\mathrm{He}$ is the second child of heaithy parents with two children. During infancy he was given the basic cholera-typhoid-para typhoid vaccinations and 3 weeks before admission the booster.

On physical examination, the boy looked very ill, the temperture was slightly increased $\left(38^{\circ} \mathrm{C}\right)$, the pulse was regular, the tongue was coated and dry, the mouth and lips were dry and fissured, heart and lungs showed no particularities, the liver was palpable two fingers below the right costal margin, the spleen was not palpable, pathologic reflexes were not present, icterus was not noted.

Laboratory findings: Hb. $11 \mathrm{gm} /$ $100 \mathrm{ml}$, leucocytes $4400 / \mathrm{mm}^{3}$ (eosinophils 0 , stab-cells 6 , polymorphs 58 , lymphocytes 34 , monocytes 2), E.S.R. $40 / 95$.

Widal reaction was negative; blood culture on Silmonolla typhi was negative; faeces culture on Salmonella typhi was pcsitive.

The diagnosis was typhoid fever. Treatment was started with absolute bed rest, classical typhus diet, chloramphenicol $100 \mathrm{mg} / \mathrm{Kg}$. body weight and vitamins. Fever subsided on the seventh day and 3 days later chloramphenicol was discontinued. The condition improved gradually.

A second blood culture on Salmonella typhi one week after hospitallization was negative, but there was a slight increase in Widlal's aggluti. nation titer of Salmonella typhi 0 antigen from zero to $1 / 100$.

At the end of the third week, the temperature rose again and the condition deteriorated; blood culture on Salmonella typhi became positive; antibiotics were given again. Six days later icterus developed and the temperature declined; the child still looked very ill. Liver function test showed: total bilirubin $2.3 \mathrm{mg} / 100 \mathrm{ml}$., direct bilirubin $1.4 \mathrm{mg} / 100 \mathrm{ml}$, T.T.T. 10.4 U Mac Lagan, Kunkel 19.5 U Mac Lagan, alkaline phosphatase 19.7 U King Amstrong. Urinalysis on bilimbin and urobilin revealed positive reaction. This indicated the presence 
of hepatitis, may be associated with typhoid fever or of viral origin. Three days after the appearance of icterus, the temperature rose again and the child vomited. On examination the child showed defence musculaire, increased pulse rate, rapid respiration. abdominal respiratory movements and absence of paristaltis. The leucocytes increased: $16.200 / \mathrm{mm}^{3}$. Intestinal perforation was suspected. The consulted surgeon advised and performed surgical intervention.

\section{Operative findings}

Approximately $50-70 \mathrm{ml}$. reddish yellow fluid was found in the peritoneal cavity. Ileum and jejunum showed no particularities. Gallbladder was slightly distended, hyperemic and two pinpoint perforations were noted at the cystic duct and at its corpus. Cholecystectomy was performed and the gallbladder was sent for pathologic examination.

\section{Pathologic findings.}

The wall of the gallbladder was oedematous, hyperemic, and showed infiltrations of inflammatory cells, consisting mostly of plasma cells, histiocytes and some polymorphonuclear leucocytes. Large mononuclear phagocytes (typhoid's cells) were also found, so that the histological picture was consistent with acute cholecystitis in typhoid fever.

\section{Postoperative course.}

The postoprative episode was uneventful. The child got vitamins, ana bolic hormones and hematinics. The boy was discharged on the twelfth week of hospitalization in a fairly good condition.

\section{Discussion}

On the basis of the clinical picture shown on admission the diagnosis was typhoid fever which was confirmed by the positive blood culture of Salmonella typhi during the relapse at the end of the third week.

The jaundice and the abnormal liver function tests indicated infectious hepatitis or liver impairment in association with typhoid fever. Liver biopsy could otherwise give the ultimate diagnosis, but it was omitted because of the bad condition. When 3 days later increased pulse rate, rapid respiration, defence musculaire, abdominal respiratory movements, absence of peristalsis and a rise of leucocytes count in the blood appeared, intestinal perforation was suspected. During the operation, however, perforation of the gallbladder was apparent. Pathologic examination of the excised gallbladder confirmed the diag. nosis of acute cholecystitis in typhoid fever.

Cholecystitis is usually associated with cholelithiasis and is very uncommon in childhood. Acute cholecystitis, however, can occur without gallstones. This is noted particularly in association with typhoid fever or other acute infections. The microbes reach 
the gallbladder either by way of the blood stream or by ascent from the duodenum. In cholecystitis edema of the bile ducts causes bile stasis and increases the pressure within the gallbladder. If softening or gangrene of the wall resulting from inflammation is present, perforation and peritonitis are likely to develop.

The peculiarity of this case is that the boy has got the proper immunizations before his illness and also the adequate medication during his hospitalization.

\section{Summary}

A case of perforation of the gallbladder in association with typhoid fever in a 5-year-old Indonesian boy has been reported. The typhoid fever was contracted in spite of previous proper immunizations and the gallbladder perforation occurred in spits of adequate treatment during hospitalization.

\section{Acknowledgement}

The authors are very grateful to the Heads of the Departments of Surgery and Pathology, Medical School, University of Pejajaran for their kind cooperation.

\section{REFERENCES}

1. ALISJAHBANA, A; TIEN SUMARTINI; WIPADISURIA, S. and SUGIRI : Salmonellosis in Infants and Children in Bandung. Paediatr. Indones. $10: 67-77$ (1970).

2. BOYD : Textbook of Pathology, p. 819 - 827, 7th Ed., (Lea \& Febiger, Philadelphia, 1961).

3. BRADFORD, W.L. : Typhoid fever; in Nelson's Textbook of Pediatrics; $p$. 585 - 588, 9th Ed. (Saunders, Philadel. phia 1969).

4. ISAAC, A. : Typhoid fever; in Brennemann/Kelley's Practice of Pediatrics
11 : 30 (Harper \& Row, Hagerstown, Maryland 1968).

5. KAYE, R. : Cholecystitis; in Nelson's Textbook of Pediatrics. p. $850-851,9$ th Ed. (Saunders, Philadelphia 1969).

6. LOZAYA : Cited by Isaac. In Brennemann/Kelley's Practice of Pediatrics 11 : 30 (Harper \& Row, Hagerstown/ Maryland 1968).

7. SELLEK, A.; CARDELLE, G. and JIMENEZ, J.A. : Salmonellosis, Typhoid fever, Shigellosis in Children; in Clinical Tropical Medicine, p. 750 (Mosby St. Louis 1951). 